\title{
Antinociceptive activity and toxicological study of aqueous extract of Egletes viscosa Less (Asteraceae)
}

\author{
Adriano Antunes S. Araújo ${ }^{1 *}$, Leonardo Rigoldi Bonjardim¹, Érica M. Mota1, Ricardo Luiz C. \\ Albuquerque-Júnior², Charles dos Santos Estevam¹, Luzia Cordeiro², Sérgio Ricardo S. Seixas ${ }^{3}$, \\ Josemar Sena Batista ${ }^{1}$, Lucindo José Quintans-Júnior ${ }^{1}$ \\ ${ }^{1}$ Departamento de Fisiologia, Universidade Federal de Sergipe, \\ ${ }^{2}$ Laboratório de Morfologia e Biologia Estrutural, Instituto de Tecnologia e Pesquisa, \\ ${ }^{3}$ Universidade Federal dos Vales do Jequitinhonha e Mucuri
}

*Correspondence:

A. A. S. Araújo

Departamento de Fisiologia

Universidade Federal de Sergipe

Av. Marechal Rondom, $\mathrm{s} / \mathrm{n}$

49000-000 - São Cristóvão - SE, Brasil E-mail: adriasa2001@yahoo.com.br
Egletes viscosa Less (Asteraceae), popularly known as "macela" or "macela-da-terra", is a plant widely used in popular medicine due to its anti-inflammatory, bactericidal, antidiarrhoea, mio-relaxant, antispasmodic, antinociceptive, digestive, and anti-viral properties. Phytochemical screening of aqueous extract of Egletes viscosa (AEEV) revealed the high presence of flavonoids. This study examined the oral antinociceptive potential of AEEV in rodents using different concentrations (100, 200, and $400 \mathrm{mg} / \mathrm{kg}, \mathrm{p} .0$.). The results showed significant antinociceptive action when tested in writhing (200 and $400 \mathrm{mg} / \mathrm{kg}-\mathrm{p}<0.05)$ and in the second phase of formalin tests $(200 \mathrm{mg} / \mathrm{kg}-\mathrm{p}<0.01$ and $400 \mathrm{mg} / \mathrm{kg}-\mathrm{p}<0.001)$. The inhibition (\%) of extract in the writhing test was $63.4,56.7$, and $79.2 \%$ respectively for 200, 400, and acetyl salicylic acid (300 mg/kg); for the formalin test (second phase) results were 66.1, 84.7, and 96.2\% respectively for 200 , 400, and acetyl salicylic acid (300 mg/kg). Collectively, these observations suggest that AEEV is effective against continuous inflammatory pain. AEEV was well tolerated. In an acute toxicity test, oral administration of $5 \mathrm{~g} / \mathrm{kg}$ of AEEV was performed and no mortality rate was observed. Similarly, in a subchronic toxicity study, no mortality was observed after 30 days of daily oral administration of $100 \mathrm{mg} / \mathrm{kg}$ of AEEV. There was no significant difference in the body and organ weights between control and experimental animals in both acute and subchronic toxicity tests. Pathological assays did not reveal any evidence of detectable differences in the gross appearance, as well as in the architectural or cellular pattern characteristics of the internal organs of the animals in both acute and subchronic tests. Nevertheless, significant differences were verified between males of the experimental and control groups regarding the levels of hemoglobin and leukocytes. In conclusion, AEEV did not induce any hazardous effects on the majority of the parameters studied. Additionally, an antinociceptive activity of the extract was verified. However, the increase in the levels of hemoglobin and leukocytes should be investigated in more detail.
Uniterms

- Egletes viscose pharmacognosy

- Egletes viscose/ experimental study

- Egletes viscose/ antinociception effect

- Phytochemical screening 


\section{INTRODUCTION}

Egletes viscosa Less (Asteraceae), popularly known as "macela", is an annual herbal plant used in Brazilian popular medicine (Lima et al., 1996). Due to its large household use for the preparation of a tea - to which emmenagogue, diaphoretic stomachic, and antidiarrhoea properties seem to be related - dried flower buds of $E$. viscosa are widely sold in herbal stores and supermarkets of the Brazilian northeast (Vieira et al., 2006). Amongst its applications, pharmacological studies showed antihepatotoxic (Rao et al., 1994), antiperoxidative (Souza et al., 1997), gastroprotective and antidiarrhoeal (Rao et al., 1997), hepatoprotective (Souza et al., 1998a), antithrombotic (Souza et al., 1994), and anti-anaphylactic and anti-inflammatory (Souza et al., 1992; Rao et al., 2003 ) properties for ternatin; antinociceptive and gastroprotective for the diterpenes (Guedes et al., 2002), and antinociceptive, anticonvulsant, and antibacterial activities for the essential oil (Souza et al., 1998b). Its natural habitat is South America, blossoming spontaneously in Uruguay, Paraguay, and in the south of Brazil. In Rio Grande do Sul it grows abundantly in wild herbal form, as much in arenaceous soil as in basaltic soil.

The use of herbal medicines or natural health products as alternative medicines for public health use continues to expand rapidly around the world. Pre-clinical assays are essential to guarantee the efficacy and safety of natural products and are commonly requested by regulatory agencies to approve marketing of these products (Remirez, 2006). In addition, the National Agency of Sanitary Surveillance (Agência Nacional de Vigilância Sanitária/ ANVISA) of Brazil published on February 24, 2000, Resolution $n^{\circ} 17$ (Brasil, 2000) establishing that phytomedicines should be submitted to pre-clinical and clinical toxicological and pharmacological assays in order to ensure the quality and safety of their use.

The aim of this present study was to evaluate the antinociceptive potential and toxicity of the aqueous extract of Egletes viscosa (AEEV).

\section{MATERIALS AND METHODS}

\section{Plant material}

The seeds of E. viscosa Less (Asteraceae) were collected from the campus of the Federal University of Sergipe, Sergipe State, Brazil, in December 2004 and were identified by Dr. Ana Paula Prata (DBI/UFS). A voucher specimen $\left(n^{\circ} 1066\right)$ is deposited at the Herbarium of the Federal University of Sergipe.

\section{Preparation of the plant extract}

An aqueous extract was obtained from the seeds of the E. viscosa harvested from the campus of the Federal University of Sergipe. After harvesting the seeds of the $E$. viscosa, they were adequately selected and then submitted to drying in a sterilizer with hot air circulation and renewal (Model MA-037) at $37^{\circ} \mathrm{C}$ until complete dehydration. Subsequently, the seeds were weighed and triturated in an electric mill until a dust of fine granulation was obtained. The aqueous crude extract of the seeds was prepared by adding $1000 \mathrm{~mL}$ of distilled water to $50 \mathrm{~g}$ of seed powder and kept at $77{ }^{\circ} \mathrm{C}$ for $30 \mathrm{~min}$. Two extractions were performed to fully extract the plant material. Then, the extract was vacuum-filtered, lyophilized, and stored in the dark at $8^{\circ} \mathrm{C}$. At the moment of use the extract was dissolved in water at the desired concentration.

\section{Phytochemical screening}

The aqueous extract was divided into different test tubes and various chemical constituents were qualitatively analyzed according to methods described by Matos (1994), and Harbone (1998). This analysis was conducted by observing colorimetric variation after the addition of specific reagents. The different chemical constituents and reagents tested included: catechins, xanthones, flavonoids, and flavononols - acid-alcohol/solid magnesium, ferric chloride reagents; saponin-frothing test.

\section{Animals}

Male and female Swiss mice (Mus muscullus) weighing 30-45 g were obtained from Tiradentes University (Sergipe, Brazil). For toxicological tests both male and female mice were used, and for nociceptive tests only male mice were used. The animals were kept under conventional conditions of temperature $\left(20 \pm 2{ }^{\circ} \mathrm{C}\right)$ and lodged in polypropylene cages, with food and water ad libitum. Experimental protocols were approved by the Committee on Animal Research at the Federal University of Sergipe $\left(n^{\circ} 05 / 2007\right)$ and conformed to the International Association for the Study of Pain (IASP) guidelines for the study of pain in animals (Zimmermann, 1983). The experiments were performed in the time period of 1:00 p.m. to 6:00 p.m.

\section{Behavioral screening}

This test was used in order to check for possible general central nervous system effects of the AEEV. Four groups of 8 mice were treated with saline $(10 \mathrm{~mL} / \mathrm{kg}$, p.o.) 
or the AEEV at the doses of 100, 200, and $400 \mathrm{mg} / \mathrm{kg}$ (p.o., at a single dose). Animals were observed for $4 \mathrm{~h}$ and their behaviors were recorded at 30,60, 120, 180, and $240 \mathrm{~min}$ after the treatment. Specific behaviors (sedation, ambulation, response to touch, analgesia, and defecation) and their intensities were observed according to Almeida et al. (1999).

\section{Analgesic activity}

Acetic acid-induced abdominal constriction (Writhing test)

This test was done using the method described by Koster et al. (1959) and Broadbear et al. (1994). Muscular contractions were induced by intraperitoneal injection (ip) of a $0.85 \%$ solution of acetic acid $(0.25 \mathrm{~mL} / \mathrm{animal})$ to a group of 8 mice. The number of muscular contractions was counted for $15 \mathrm{~min}$ after injection and the data represents the average of the total number of writhes observed. The AEEV (100, 200 , and $400 \mathrm{mg} / \mathrm{kg}$ ) or the acetylsalicilic acid reference drug (ASA), in doses of $300 \mathrm{mg} / \mathrm{kg}$, were administered orally $1 \mathrm{~h}$ before the acetic acid injection.

\section{Formalin test}

The observation chamber was a glass box of $30 \mathrm{~cm}$ diameter on a transparent acrylic plate floor. Beneath the floor, a mirror was mounted at a $45^{\circ}$ angle to allow clear observation of the paws of the animals. The animals ( $n=8 /$ per group) were treated with the vehicle (Saline), $\operatorname{AEEV~}(100,200$, and $400 \mathrm{mg} / \mathrm{kg}$, p.o.), or ASA (300 mg/ $\mathrm{kg}) 1 \mathrm{~h}$ before formalin injection. Each mouse was placed in the chamber more than 5 min before treatment in order to allow acclimatization to the new environment. The formalin test was carried out as described by Hunskaar and Hole (1987). Twenty microliters of a $2.5 \%$ formalin solution $(0.92 \%$ formaldehyde $)$ in a phosphate-buffer were injected in the dorsal surface of the left hind paw using a microsyringe with a 26-gauge needle. Each animal was then returned to the chamber and the amount of time that the animal spent licking the injected paw was considered as indicative of pain. Two distinct phases of intensive licking activity were identified: an early acute phase $(0-5 \mathrm{~min} /$ phase 1) and a late or tonic phase (15-30 min/phase 2).

\section{Toxicological studies}

\section{Acute toxicity study}

The animals were distributed in four groups $(\mathrm{n}=6 \mathrm{per}$ group) and kept in adequately maintained boxes, which had been previously named as box I and II (composed of male and female control groups, respectively) and boxes III and
IV (composed of male and female experimental groups). The animals were submitted to crescent doses $(1,3$, and $5 \mathrm{~g} / \mathrm{kg}$ ) managed by oral administration (gavage), adopting $5 \mathrm{~g} / \mathrm{kg}$ as the maximum dose to be used.

Specific behaviors (sedation, ambulation, response to touch, analgesia, and defecation) and their intensities were observed according to Almeida et al. (1999) for 1, 2, 3, and $4 \mathrm{~h}$ after gavage. Finally, the animals were observed daily for 14 days to verify lethality.

\section{Subchronic toxicity study}

Toxicological assays were performed with 12 male and 12 female mice, whose weights ranged from 30 to $45 \mathrm{~g}$, distributed in 4 groups of 6 animals (experimental and control groups of male and female mice). For the subchronic study, daily doses of the extract $(100 \mathrm{mg} / \mathrm{kg})$ were given to the experimental groups over a period of 30 days, while only water was given to the control group. Subsequently, the animals were sacrificed and a detailed study of gross and microscopic features of internal organs, as well as hematological and biochemical analyses of blood were carried out. The position, shape, size, texture, consistency, and color of internal organs (lungs, heart, liver, intestines, and kidneys) were macroscopically observed looking for any signs of gross changes These organs were then collected, weighed to determine relative organ weights, and preserved in $10 \%$ phosphate buffered formalin solution for subsequent histological procedures.

\section{Parameters}

\section{Hematological analysis}

All surviving animals fasted overnight and were anesthetized afterwards for blood collection from a common carotid artery. Blood samples were collected into heparinized and dry non-heparinized centrifuge tubes. Blood $(1 \mathrm{~mL})$ from the mice was collected from the carotid artery into syringes and immediately analyzed for the estimation of number of erythrocytes $\left(10^{6} / \mathrm{mm}^{3}\right)$, hemoglobin $(\mathrm{Hb}, \mathrm{g} / \%)$, hematocrit (packed cell volume, $\%)$, the mean corpuscular volume $\left(\mathrm{MCV}, \mathrm{mcm}^{3}\right)$, the mean corpuscular hemoglobin ( $\mathrm{MCH}, \mathrm{mmg})$, the mean corpuscular hemoglobin concentration (MCHC, \%), and total white blood cells (WBCs): lymphocytes, leucocytes $\left(\mathrm{p} / \mathrm{mm}^{3}\right)$, segmented, eosinophils, neutrophils, and monocytes.

\section{Tissue analysis}

Formalin-fixed samples of the internal organs were dehydrated, diafanized, and embedded in paraffin according to routine protocol of histological procedures. 
Five micrometer thin sections of the paraffin-embedded tissues were obtained and stained by means of hematoxilineosin histochemical method. Morphological analysis of the histological sections was performed by light microscopy following a closed numerical protocol in such a manner as the pathologist was not aware of what group was being evaluated until the end of the experiment.

\section{Statistical analysis}

Both analysis of variance (ANOVA) and Student's $t$ test (Origin 6.2 computer program) were employed to carry out the statistical analysis of the results. All values were expressed as back transformed mean \pm standard deviation. Differences below the probability level of 0.05 were considered statistically significant. The percent of inhibition by an antinociceptive agent was determined for each experimental group using the following formula (Reanmongkol et al., 1994):

inhibition $\%=100$. (control-experiment $) /$ control

\section{RESULTS AND DISCUSSION}

\section{Phytochemical tests}

Phytochemical screening of the AEEV showed the presence of saponin, catechins, flavonoids, flavononols, and xanthones. The number of positive signs indicated high quantity flavonoids (Table I).

TABLE I - Phytochemical screening of aqueous extract of Egletes viscosa

\begin{tabular}{lc}
\hline Parameters & Extract \\
\hline Colour & Reddish brown \\
Catechins & + \\
Saponin & + \\
Flavonoids & +++ \\
Flavononols & + \\
Xanthones & + \\
\hline
\end{tabular}

+ Positive test; +++ quantitative presence.

\section{Analgesic activity}

\section{Writhing test}

The number of writhes during the $15 \mathrm{~min}$ test period was statistically lower in doses of $200(\mathrm{p}<0.05)$ and $400 \mathrm{mg} / \mathrm{kg}(\mathrm{p}<0.05)$ of AEEV than in the control group (Figure 1). Although these results are significant, the inhibition (\%) of nociceptive behavior by the 200 and $400 \mathrm{mg} / \mathrm{kg}$ (63.4 and $56.7 \%$ ) doses was inferior to that produced by the reference drug, ASA-300 mg/kg (79.2\%).
The AEEV inhibited acetic acid-induced writhing in mice. In acetic acid-induced abdominal writhing, pain is elicited by the injection of an irritant such as acetic acid into the peritoneal cavity which produces episodes of characteristic stretching (writhing) movements, and the inhibition of the number of episodes by analgesics is easily quantifiable.

Despite the significant results obtained, the abdominal writhing test model has been reported to be a less selective model. In the writhing test, both central and peripheral analgesics can be detected because of the lack of specificity (Abdollahi et al., 2003). Thus, caution is required in interpreting the results and other tests should be performed.

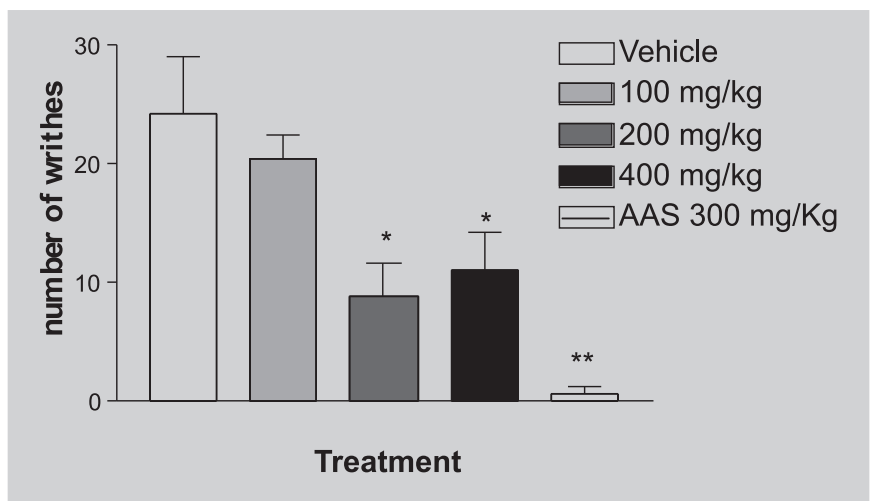

FIGURE 1 - Antinociceptive effects of aqueous extract of Egletes viscosa on acetic acid-induced abdominal writhes. Values are significant at $* \mathrm{P}<0.05 ; * * \mathrm{P}<0.001$ vs. saline + extract; ANOVA+Dunnet.

\section{Formalin test}

In the first phase AEEV did not show any significant effect on nociception (Figure 2). Oral administration of AEEV, in doses of $200(\mathrm{p}<0.01)$ and $400 \mathrm{mg} / \mathrm{kg}(\mathrm{p}<$ 0.001 ), reduced statistically pain in the second phase of the formalin test, as shown in Figure 3. This decrease occurred in a dose dependent manner. Moreover, the inhibition \% by 200 and $400 \mathrm{mg} / \mathrm{kg}$ extracts was inferior to that produced by the reference drug-ASA-300 $\mathrm{mg} / \mathrm{kg}(66.1,84.7$, and $96.2 \%$ respectively).

A subcutaneous injection of formalin produces a distinct biphasic nociception. The first phase starts immediately after the formalin injection and continues for $5 \mathrm{~min}$, after which nociception appears to diminish. The second phase begins as a return to high levels of nociception beginning 15 30 min after the formalin injection and continues for 60 min (Hunskaar, Hole, 1987). These phases have obvious, different properties and are very useful tools, not only for assessing the potency of analgesics, but also for elucidating the mechanisms of pain and analgesia. The action of analgesics is different in the first and second 
phases. Drugs such as narcotics (e.g. morphine, codeine, meperidine) which primarily act centrally, inhibit both phases equally (Hunskaar et al., 1985; Shibata et al., 1989; Vaccarino et al., 1989; Chen et al., 1995), but peripherally acting drugs such as aspirin, oxyphenbutazone, dexamethasone, and hydrocortisone only inhibit the second phase of formalin-induced nociception (Shibata et al., 1989; Chen et al., 1995). In the present study, AEEV only inhibits the second phase of the formalin test, although during behavioral screening the highest dose of AEEV showed depressant activity. Flavonoids were found to be the main component of this extract, which could explain its analgesic effects. It has been reported that flavonoids may interact directly with the prostaglandin system (Panthong et al., 1989; Recio et al., 1995). In addition, Rao et al. (2003) reported that ternatin, a flavonoid from Egletes viscosa Less, exerts its anti-inflammatory action, at least in part, through inhibition of neutrophil migration and modulation of macrophage function.

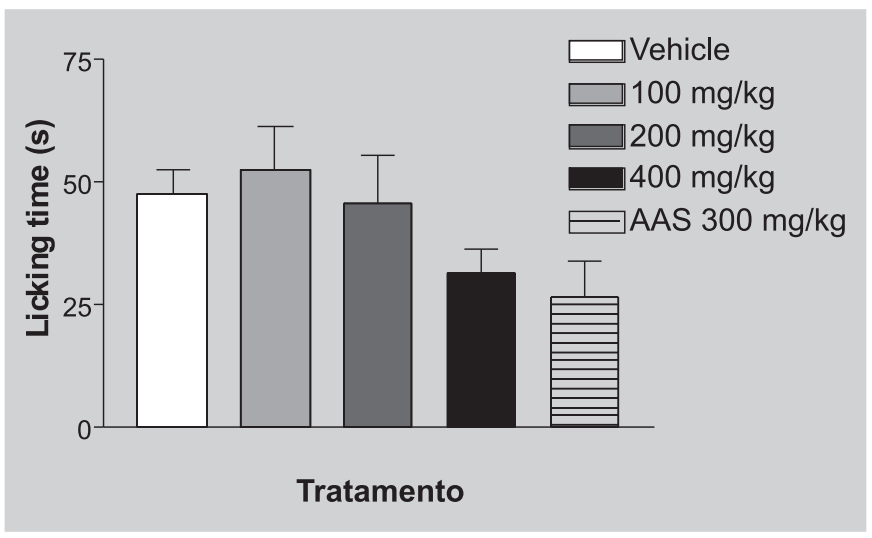

FIGURE 2 - Antinociceptive effects of aqueous extract of Egletes viscosa on first phase of the formalin test

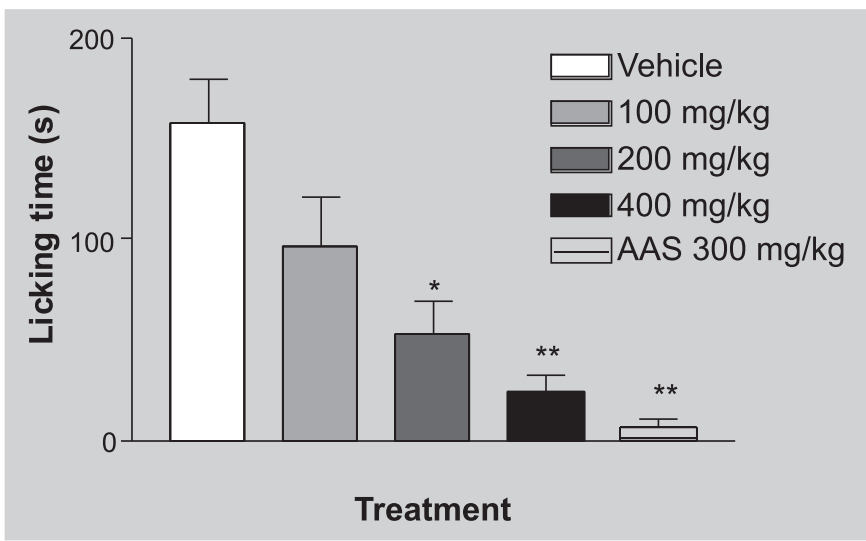

FIGURE 3 - Antinociceptive effects of aqueous extract of Egletes viscosa on second phase of the formalin test. Values are significant at $* \mathrm{P}<0.01 ; * * \mathrm{P}<0.001$ vs. control; ANOVA+Dunnet

\section{Toxicological studies}

The tests for acute toxicity from the aqueous extract of $E$. viscosa did not demonstrate signs of lethality in mice until the maximum dose of $5 \mathrm{~g} / \mathrm{kg}$ was given by oral administration. A $5 \mathrm{~g} / \mathrm{kg}$ body weight dose was considered as the "Limit test", as recommended by acute toxicity testing procedures. Therefore, administration of further higher doses was considered physiologically unsound and is not generally recommended (Muralidhara et al., 1999; Barros et al., 2005). In regard to behavioral screening, the aqueous extract of $E$. viscosa at a dose of $400 \mathrm{mg} / \mathrm{kg}$ (p.o.) produced sedation, a decrease of ambulation, and a reduction of response to touch, analgesia, and a decrease of defecation. However, at doses of 100 and $200 \mathrm{mg} / \mathrm{kg}$ (p.o.) no major effects on the nervous system were revealed. Thus, the highest dose of AEEV was indicative of depressive activity on the CNS according to Almeida et al. (1999). Nevertheless, it is necessary to determine the major evidence indicating depressant activity as well as the possible action mechanisms (Franco et al., 2005).

Oral administration of $E$. viscosa seed extract for 30 days did not cause any appreciable alterations in water and food intake in any of the groups. Moreover, body weight gain during the observation period among the treated animals (experimental groups) was comparable to their respective control group $(\mathrm{p}>0.05)$. The body weights of all animals were measured every week throughout the study (Fig. 4).

At necropsy, no significant changes in the vital organ weights were seen in any of the male and female mice

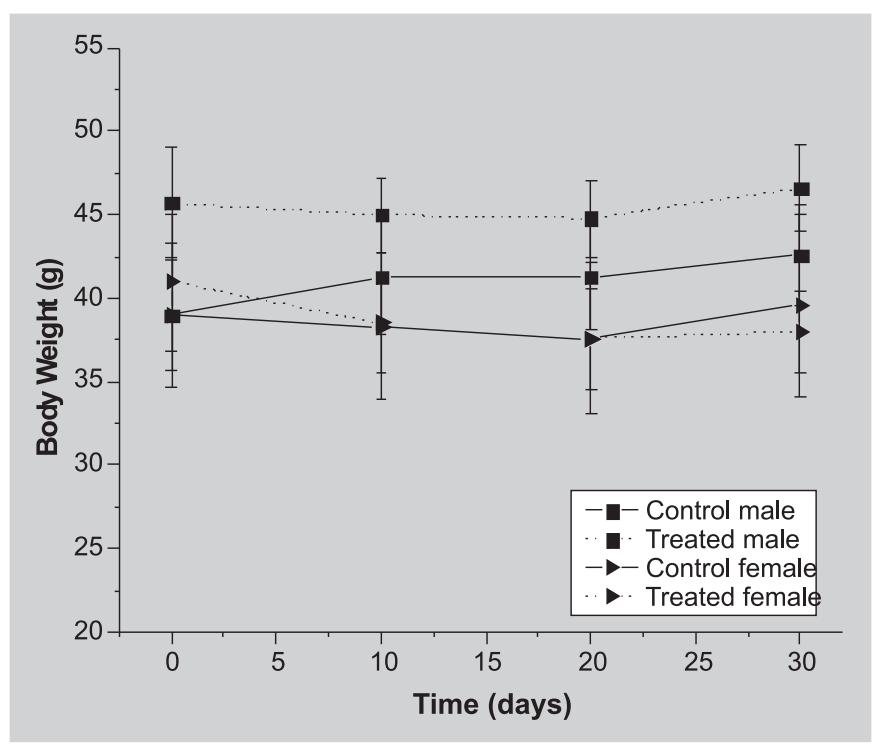

FIGURE 4 - Body weight curves for male and female mice treated with aqueous extract of Egletes viscosa or saline solution for 30 days. 
treated with aqueous extract of E. viscosa as compared with the control groups $(p>0.05)$ (Table II). These results clearly indicate that AEEV does not interfere in the normal weight of the available organs.

The administration of oral doses of the AEEV did not cause erythrocyte, hematocrit, $\mathrm{MCV}, \mathrm{MCH}, \mathrm{MCHC}$, segmented neutrophils, eosinophils, lymphocytes, and monocytes serum levels to change (Table III and Table IV). However, a significant increase in hemoglobin and leukocyte values was observed for the male experimental group $(\mathrm{p}<$ $0.05)$ when compared to the male control group. This significant difference was not verified between the females groups. In addition, no evidence of changes in body weight and animal behavior, as well as in the histological architecture of the internal organs, was found. Therefore, these outcomes suggested the absence of any hematotoxic potency of AEEV, although the increase in levels of hemoglobin and leukocytes should be investigated in more detail.

Pathological examination of the tissues on a gross basis indicated that there were no detectable abnormalities, neither in weight nor in appearance, and no significant differences were grossly detected between control and experimental groups. Moreover, the organs of both groups were unremarkable and comparable to each sex. Microscopical analysis of the examined internal organs revealed that their architectural and cellular appearance were comparatively unremarkable in both groups and sexes. Nevertheless, all pulmonary samples from both ex-

TABLE II - Organs weight for male and female mice treated with aqueous extract of Egletes viscosa or saline solution for 30 days

\begin{tabular}{lcccc}
\hline & & Organ weights & \\
Group & Lungs $(\mathrm{mg})$ & Heart $(\mathrm{mg})$ & Liver $(\mathrm{mg})$ & Kidneys $(\mathrm{mg})$ \\
\hline $\mathrm{CM}$ & $253 \pm 47$ & $206 \pm 23$ & $1800 \pm 0.12$ & $512.7 \pm 60.2$ \\
TM & $218 \pm 33$ & $198 \pm 17$ & $1830 \pm 0.06$ & $521.9 \pm 63.9$ \\
CF & $205 \pm 39$ & $161 \pm 8$ & $1540 \pm 0.18$ & $345.4 \pm 33.5$ \\
TF & $249 \pm 26$ & $187 \pm 33$ & $1720 \pm 0.43$ & $372.5 \pm 43.1$ \\
\hline
\end{tabular}

* CM (controlled male), TM (treated male), CF (controlled female) and TF (treated female).

TABLE III - The effect of aqueous extract of Egletes viscosa on differential count of blood (red series) of the sub-chronic study. (mean \pm SD)

\begin{tabular}{lcccccc}
\hline Values & $\begin{array}{c}\text { Erythrocytes } \\
\left(\mathrm{milh} / \mathrm{mm}^{3}\right)\end{array}$ & $\begin{array}{c}\text { Hemoglobin } \\
(\mathrm{g} / \%)\end{array}$ & $\begin{array}{c}\text { Hematocrit } \\
(\%)\end{array}$ & $\begin{array}{c}\mathrm{MCV} \\
\left(\mathrm{mcu}^{3}\right)\end{array}$ & $\begin{array}{c}\text { MCH } \\
(\text { uug })\end{array}$ & $\begin{array}{c}\text { MCHC } \\
(\%)\end{array}$ \\
\hline $\mathrm{CM}$ & $5.18 \pm 0.7$ & $8.70 \pm 0.4$ & $27.60 \pm 3.4$ & $52.35 \pm 2.9$ & $16.63 \pm 1.7$ & $31.77 \pm 2.9$ \\
$\mathrm{TM}$ & $6.34 \pm 1.0$ & $10.30 \pm 1.2 *$ & $33.10 \pm 6.3$ & $52.09 \pm 2.0$ & $16.35 \pm 1.0$ & $31.45 \pm 2.6$ \\
$\mathrm{CF}$ & $4.85 \pm 1.9$ & $8.90 \pm 2.5$ & $28.65 \pm 8.9$ & $61.70 \pm 9.9$ & $19.46 \pm 3.1$ & $31.57 \pm 2.1$ \\
$\mathrm{TF}$ & $6.28 \pm 0.36$ & $9.90 \pm 0.65$ & $33.76 \pm 2.0$ & $53.70 \pm 0.5$ & $15.76 \pm 0.3$ & $29.32 \pm 0.8$ \\
\hline
\end{tabular}

CM (control male), TM (treated male), CF (control female) and TF (treated female). MCV- Mean Corpuscular Volum, MCH- Mean Corpuscular Hemoglobin, MCHC- Mean Corpuscular Hemoglobin Concentration * Values are significant at $\mathrm{P}<0.05$ vs. control; Student's $t$-test.

TABLE IV - The effect of aqueous extract of Egletes viscos $a$ on differential count of blood (white series) of the sub-chronic study. (mean \pm SD)

\begin{tabular}{lccccc}
\hline & Leukocytes $\left(\mathrm{p} / \mathrm{mm}^{3}\right)$ & Neutrophils & Eosinophils & Lymphocytes & Monocytes \\
\hline $\mathrm{CM}$ & $1.233 \pm 450$ & $25 \pm 3.3$ & $0.50 \pm 0.6$ & $71.0 \pm 2.8$ & $3.0 \pm 0.8$ \\
$\mathrm{TM}$ & $2.266 \pm 926^{*}$ & $32 \pm 6.9$ & $0.50 \pm 0.5$ & $63.0 \pm 6.4$ & $3.0 \pm 0.8$ \\
$\mathrm{CF}$ & $2.250 \pm 858$ & $42 \pm 6.4$ & $1.25 \pm 0.5$ & $52.5 \pm 6.5$ & $3.5 \pm 0.6$ \\
$\mathrm{TF}$ & $1.300 \pm 264$ & $34 \pm 9.6$ & $1.33 \pm 1.1$ & $61.6 \pm 10$ & $3.0 \pm 0.0$ \\
\hline
\end{tabular}

$\mathrm{CM}$ (control male), TM (treated male), CF (control female) and TF (treated female). ${ }^{*}$ Values are significant at $\mathrm{P}<0.05$ vs. control; Student's $t$-test. 
perimental and control groups revealed a picture of slight and focal atelectasy. This morphological alteration might have been a result of some already expected changes in their blood pressure and respiratory rhythm, probably due to the conditions of continuous stress caused by experimental manipulation of the animals. Therefore, it seems absolutely clear that the focal morphological picture of atelectasy is not related to the aqueous extract of $E$. viscosa Less oral administration, as it was observed in both experimental and control groups.

\section{CONCLUSION}

It is concluded that the aqueous extract of Egletes viscosa did not induce any hazardous effects on the majority of the parameters studied and showed antinociceptive properties. The extract will, therefore, be of potential benefit in the management of inflammatory pain disorders. Further studies currently in progress will enable as to understand the mechanisms of action underlying the effects observed in this investigation. In acute and subchronic toxicity tests no mortality rate was observed. There was no significant difference in the body and organ weights between control and experimental animals in both acute and subchronic toxicity tests. Pathological assays did not reveal any evidence of detectable differences in the gross appearance, as well as in the architectural or cellular pattern characteristics of the internal organs of the animals in both acute and subchronic tests.

\section{RESUMO}

\section{Atividade antinociceptiva e estudo toxicológico de extrato aquoso de Egletes viscosa Lessa (Asteraceae)}

Egletes viscosa Less (Asteraceae), popularmente conhecida como "macela" ou "macela-da-terra", é uma planta largamente usada na medicina popular devido as suas propriedades: anti-inflamatória, bactericida, antidiarréica, mio-relaxante, anti-espasmódica, antinociceptiva, digestiva e anti-viral. Análise fitoquímica do extrato aquoso da Egletes viscosa (AEEV) mostrou elevada presença de flavonóides. Este estudo examinou o potencial antinociceptivo do AEEV em roedores usando diferentes concentrações (100, 200 and $400 \mathrm{mg} / \mathrm{kg}$, p.o.). Os resultados mostraram significante efeito antinociceptivo quando testadas as doses $(200 \mathrm{mg} / \mathrm{kg}$ $p<0.01 ; 400 \mathrm{mg} / \mathrm{kg}-\mathrm{p}<0.05)$ e na segunda fase dos testes com formalina (200 and $400 \mathrm{mg} / \mathrm{kg}-\mathrm{p}<0.001)$. Este efeito antinociceptivo foi similar ao ácido acetilsalicílico
(300 mg/kg) nas doses de 200 e $400 \mathrm{mg} / \mathrm{kg}$. Adicionalmente, estas observações sugerem que o AEEV é efetivo contra dores inflamatórias contínuas. AEEV foi bem tolerada. No teste de toxicidade aguda, utilizando uma administração oral de $5 \mathrm{~g} / \mathrm{kg}$ de AEEV, não foi observado casos de mortalidade. Da mesma maneira, no estudo subcrônico nenhuma mortalidade foi observada após 30 dias de administração oral diária de $100 \mathrm{mg} / \mathrm{kg}$ do AEEV. Não houve diferença significativa entre os pesos corporal e dos órgãos isolados quando comparados grupo controle e teste tanto no estudo agudo quanto subcrônico. Ensaios histopatológicos não revelaram diferenças entre a aparência dos tecidos, assim como na estrutura celular dos órgãos dos animais do estudo agudo e subcrônico. No entanto, diferenças significativas foram verificadas entre os machos do grupo experimental e controle quanto à hemoglobina e leucócitos. Conclui-se que o extrato estudado não induziu nenhum risco na maioria dos parâmetros avaliados e, ainda, mostrou efeito antinociceptivo. No entanto, o aumento dos níveis de hemoglobina e leucócitos devem ser melhor investigados.

UNITERMOS: Egletes viscosa/farmacognosia. Egletes viscosa/estudo experimental. Egletes viscosa/ efeito antinocicepitivo. Triagem fitoquímica.

\section{ACKNOWLEDGEMENTS}

We would like to thank the National Council of Technological and Scientific Development (Conselho Nacional de Desenvolvimento Científico e Tecnológico/ $\mathrm{CNPq} /$ Brazil)) and the Research Supporting Foundation of State of Sergipe (Fundação de Amparo à Pesquisa do Estado de Sergipe/FAPITEC-SE) for the financial support.

\section{REFERENCES}

ABDOLLAHI, M.; KARIMPOURA, H.; MONSEFESFEHANIB, H. R. Antinociceptive effects of Teucrium polium L. total extract and essential oil in mouse writhing test. Pharmacol. Res., v.48, p.31-35, 2003.

BARROS, S.; ROPKE, C.D.; SAWADA, T.C.H.; SILVA, V.V.; PEREIRA, S.M.M.; BARROS, S.B.M. Assessment of acute and subchronic oral toxicity of ethanolic extract of Pothomorphe umbellata L. Miq (Pariparoba). Rev. Bras. Ciênc. Farm, v.41, p.53-61, 2005. 
BRASIL. Ministério da Saúde. (2000) Agência Nacional de Vigilância Sanitária. Resolução RDC n ${ }^{\circ} 17$ de 24 fev. 2000. Dispõem sobre o registro de medicamentos fitoterápicos, Diário Oficial da União, Brasília, 25 fev. 2000. Disponível em: $<\mathrm{http} / /$ www.anvisa.gov.br/resol/ 2000/17_00rdc.htm/>. Acesso em: 04 abr. 2002.

BROADBCAR, J.H.; NEGUS, S.S.; BUTELMAN, E.R.; COSTA, B.R.; WOODS, J.H. Differential effects of systemically administered nor-binaltorphimine (nor-BNI) on k-opioid agonists in mouse writhing assay. Psychopharmacology I., v.15, p.311-319, 1994.

CHEN, Y.F.; TSAI, H.Y.; WU, T.S. Anti-inflammatory and analgesic activities from root of Angelica pubescens. Planta Med., v.61, p.2-8, 1995.

FRANCO, C.I.F.; MORAIS, L.C.S.L.; QUINTANSJÚNIOR, L.J.; ALMEIDA, R.N.; ANTONIOLLI, A.R. CNS pharmacological effects of the hydroalcoholic extract of Sida cordifolia L. leaves. J. Ethnopharmacol. v.98, p.275-279, 2005.

GUEDES, M.M.; CUNHA, N.A.; SILVEIRA, E.R.; RAO, V.S.N. Antinociceptive and gastroprotective effects of diterpenes from the flower buds of Egletes viscosa. Planta Med., v.68, p.1044-1046, 2002.

HARBORNE, J.B. Phytochemical methods: a guide to modern techniques of plant analysis. 3. ed. New York: Chapman and Hall Co.,1998. p.302.

HUNSKAAR, S.; FASMER, O.B.; HOLE, K. Formalin test in mice, a useful technique for evaluating mild analgesics. J. Neurosci. Methods. v.14, p.69-76, 1985.

HUNSKAAR, S.; HOLE, K. The formalin test in mice: dissociation between inflammatory and non-inflammatory pain. Pain. v.30, p.103-104, 1987.

KOSTER, R.; ANDERSON, M.; BEER, E.J. Acetic acid for analgesic screening. Fed. Proc., v.18, p.412-416, 1959.

LIMA, M.A.S.; SILVEIRA, E.R.; MARQUES, M.S.L.; SANTOS, R.H.A.; GAMBARDELA, M.T.P. Biologically active flavonoids and terpenoids from Egletes viscosa. Phytochemistry, v.41, p.217-223, 1996.

MATOS, F.J.A. Introdução à Fitoquímica Experimental. Fortaleza: Ed. UFC, 1994. p.128.
MURALIDHARA; NARASIMHAMURTHY, K.; VISWANATHA, S.; RAMESH. B.S. Acute and subchronic toxicity assessment of debitterized fenugreek powder in the mouse and rat. Food Chem. Toxicol., v.37, p.831-838, 1999.

PANTHONG, A.; TASSANEEYAKUL, W.; KANJANAPOTHI, D.; TANTIWACHWUTTIKUL, P.; REUTRAKUL, V. Anti-inflammatory activity of 5,7 dimethoxy-flavon. Planta Med., vn.55, p.133-136, 1989.

QUINTANS-JÚNIOR, L. J.; FALCÃO, A. C. G. M.; DINIZ, R. S. T.; ALMEIDA, R. N.; POLARI, R. M.;BARBOSA FILHO, J. M.; AGRA, M. F.; DUARTE, J. C.; FERREIRA, C. D.; ANTONIOLLI, A. R.; ARAÍJO, C. C. Metodologia para avaliação de plantas com atividade no sistema nervoso central e alguns dados experimentais. Rev. Bras. Cienc. Farm., v.80, p.72-76, 1999

RAO, V.S.N.; FIGUEIREDO, E.G.; MELO, C.L.; VIANA, G.S.B.; MENEZES, D.B.; MATOS, M.S.F.; SILVEIRA E.R. Protective effect of ternatin, a flavonoid isolated from Egletes viscosa Less., in experimental liver injury. Pharmacology, v.48, n.3/4, p.392-397, 1994.

RAO, V.S.N.; SANTOS, F.A.; SOBREIRA, T.T.; SOUZA, M.F.; MELO, C.L.; SILVEIRA, E.R. Investigations on the gastroprotective and antidiarrhoeal properties of ternatin, a tetramethoxyflavone from Egletes viscosa. Planta Med., v.63, p.146-149, 1997.

RAO, V.S.N.; PAIVA, L.A.F.; SOUZA, M.F.; CAMPOS, A.R.; RIBEIRO, R.A.; BRITO, G.A.C.; TEIXEIRA, M.J.; SILVEIRA, E.R. Ternatin, an anti-inflammatory flavonoid, inhibits thioglycolate-elicited rat peritoneal neutrophil accumulation and LPS-activated nitric oxide production in murine macrophages. Planta Med., v.69, p.851-853, 2003.

REMIREZ, D.C. Update in Pre-Clinical Regulatory Requirements for Phytomedicines in Latin America. Journal of Complementary and Integrative Medicine. 3(1), Article 3. Available at: <http://www.bepress.com/ $\mathrm{jcim} / \mathrm{vol} 3 / \mathrm{iss} 1 / 3,2006>$. Acessed in: 06 fev. 2008.

REANMONGKOL, W.; MATSUMOTO, K.; WATANABE, H.; SUBHADHIRASAKUL, S.; SAKAI, S.I. Antinociceptive and antipyretic effects of alkaloids extracted from the stem bark of Hunteria zeylanica. Biol. Pharm. Bull., v.17, p.1345-1350, 1994. 
RECIO, M.C.; GINER, R.M.; MANES, S.; TALENS, A.; GUBELLS, L.; GUEHO, J. Anti-flammatory activity of flavonol glycosides from Erythrospermum monticolum depending on single or repeated local TPA administration. Planta Med., v.61, p.502-504, 1995.

SHIBATA, M., OHKUBO, T., TAKAHASHI, H., INOKI, R. Modified formalin test: characteristic biphasic pain response. Pain., v.38, p.347-352, 1989.

SOUZA M.F., RAO V.S.N., SILVEIRA E.R. Antianaphylactic and anti-inflammatory effects of ternatin, a flavonoid isolated from Egletes viscosa Less. Braz. J. Med. Biol. Res., v.25, p.1029-1032, 1992.

SOUZA, M.F.; CUNHA, G.M.A.; FONTENELE, J.B.; VIANA, G.S.B.; RAO, V.S.N. Antithrombotic activity of ternatin, a tetramethoxy flavone from Egletes viscosa Less. PTR, Phytotherapy Res., v.8, p.478-481, 1994.

SOUZA, M.F.; RAO, V.S.N.; SILVEIRA E.R. Inhibition of lipid peroxidation by ternatin, a tetramethoxyavone from Egletes viscosa L. Phytomedicine, v.4, p.27-31, 1997.
SOUZA, M.F.; RAO, V.S.N.; SILVEIRAE.R. Prevention of acetaminophen-induced hepatotoxicity by ternatin, a bioflavonoid from Egletes viscosa Less. PTR, Phytother. Res., v.12, p.557-561, 1998a.

SOUZA, M.F.; SANTOS, F.A.; RAO, V.S.N.; SIDRIM, J.J.C.; MATOS, F.J.A.; MACHADO, M.I.L.; SILVEIRA, E.R. Antinociceptive, anticonvulsant and antibacterial effects of the essential oil from the flower heads of Egletes viscosa L. PTR, Phytother. Res., v.12, p.28-31, 1998b.

VACCARINO, A.L.; TASKER, R.A.R.; MELZACK, R. Analgesia produced by normal doses of opioid antagonists alone and in combination with morphine. Pain. v.36, p.103-109, 1989.

VIEIRA, G.A.B.; LIMA, M.A.S.; BEZERRA, A.M.E.; SILVEIRA, E.R. Chemical composition of teas from two cultivated chemotypes of Egletes viscosa ("Macela-daterra"). J. Braz. Chem. Soc.v.17, p.43-47, 2006.

ZIMMERMANN, M. Ethical guidelines for investigations of experimental pain in conscious animals. Pain., v.16, p.109-110, 1983.

Recebido para publicação em 18 de janeiro de 2008 Aceito para publicação em 24 de julho de 2008 